\title{
Seabirds as monitor organisms of contaminants along the German North Sea coast*
}

\author{
Peter H. Becker \\ Institut für Vogelforschung; \\ D-2940 Wilhelmshaven 15, FRG
}

\begin{abstract}
In the 1980s, significant regional, interspecific and annual differences in contamination with toxic chemicals were found in eggs of breeding birds along the German North Sea coast. In some regions residue levels approached a range endangering breeding success, especially in terns. In 1987, a three-year monitoring-program for common tern Sterna hirundo and oystercatcher Haematopus ostralegus was started, in order to recognize such contamination trends. Eggs from 9-14 areas along the coast are now being analysed for chlororganic residues and mercury. First results on geographical and year-to-year variation are presented here, and the advantages of seabird eggs as spatial and temporal monitors of marine pollution are discussed. The suggestion is made to include a shore-breeding bird species in the European monitoring programs.
\end{abstract}

\section{INTRODUCTION}

Seabirds have often been indicators of toxic chemicals in the marine environment (e.g. Robinson et al., 1967; Koeman, 1971; Blus et al., 1977; Ohlendorf et al., 1978). Consequently, in several countries they are used as monitor organisms (e.g. Coulson et al., 1972; Nisbet \& Reynolds, 1984; Mineau et al., 1984; Olsson \& Reutergardh, 1986; Gilbertson et al., 1987). The contamination of coastal birds along the North Sea coasts, however, seems to have been little studied concerning spatial or temporal trends (e.g. NERC, 1983; Goede, 1985; Moksnes \& Norheim, 1986; Becker et al., 1985a, b, 1988), and this in spite of the fact that

(1) the North Sea supports many internationally important populations of seabirds, shorebirds and waterfowl which make use of this area for breeding, feeding, migrating or overwintering (e.g. Tasker \& Pienkowski, 1987);

(2) the problems of North Sea pollution have been increasing (e.g. Buchwald, 1985), and

(3) seabirds occupy higher positions in the food web, which implies that they are especially vulnerable to persistent chemical pollutants such as organochlorines. These cause mortality, breeding failure and population decrease, as was documented in seabirds and waders in the Wadden Sea during the 1960s (Koeman, 1971; Swennen, 1972; Duinker \& Koeman, 1978; Becker \& Erdelen, 1987).

\footnotetext{
- Presented at the VI International Wadden Sea Symposium (Biologische Anstalt Helgoland, Wattenmeerstation Sylt, D-2282 List, FRG, 1-4 November 1988)
} 
In this paper the usefulness of coastal breeding birds as monitors of persistent pollutants in the marine environment is evaluated. First results of a current monitoring program on the German Wadden Sea coast from 1987 are presented and compared with data from corresponding studies in 1981 and 1986.

\section{METHODS}

In 1987, the Institut für Vogelforschung started a three-year monitoring study along the German North Sea coast, in cooperation with the Chemisches Institut der Tierärztlichen Hochschule in Hannover and with the financial support of the Umweltbundesamt (Federal German Environment Office) in Berlin. Two monitor species, differing completely in their biology, were selected: the oystercatcher Haematopus ostralegus, feeding on mussels and worms on intertidal flats and in a low position on the food web, and the common tern Sterna hirundo, a fish-eating species in a higher position and consequently more contaminated and threatened by environmental chemicals. In contrast to the oystercatcher which mostly stays over winter in the Wadden Sea, the common tern is a long-distance migrant, wintering in West Africa (e.g. Glutz \& Bauer, 1975, 1982). We

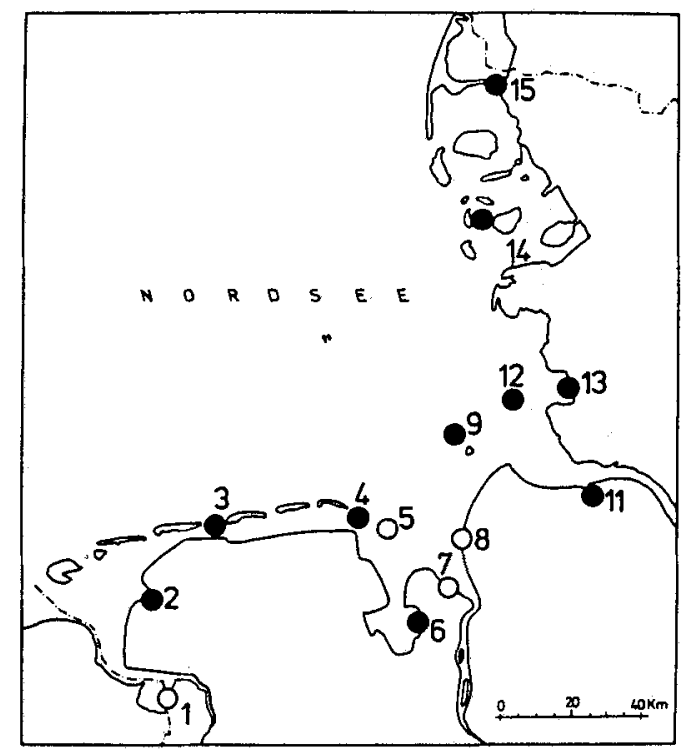

Fig. 1. Monitoring project along the German North Sea coast 1987-1989: the symbols refer to sampling areas for eggs of oystercatchers only (o), of oystercatchers and common terns (๑) or just common tern eggs (area 4 only)

Fig. 2. Geographic variation in concentrations of organochlorines and mercury in eggs of oystercatchers from the German North Sea coast in 1987. For the location of the sampling areas (numbers 1-15) see Figure 1. Residue levels are given in $\mathrm{mg} / \mathrm{kg}$ wet weight as mean (column) + sd (narrow column), geometric mean (horizontal lines) and range (vertical lines). Other than area $7(n=7), 10$ eggs per area were analysed (one egg/clutch). Area numbers below the columns indicate significant intersite differences (at least $p<0.05$, Scheffé-test with $\log 10$ of the residue levels; in each case, numbers are given only below the higher of the two contaminated areas compared) 
Seabirds as monitor organisms of contaminants

397
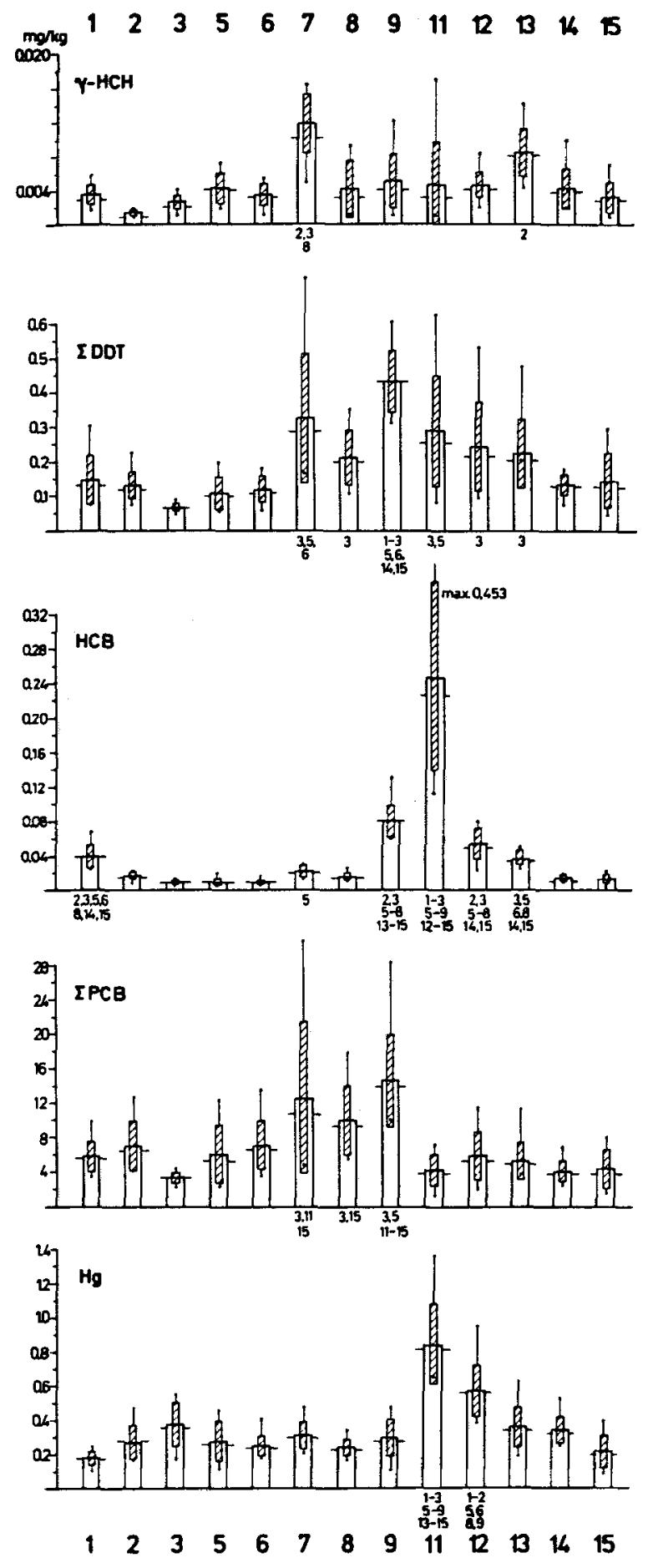
have at our disposal detailed knowledge on the breeding, feeding and population biology of both species in the Wadden Sea area. Furthermore, in other projects of our institute, their biology is being studied producing background information essential for their utilization as monitors.

From 9-14 areas on the German North Sea coast 10 fresh eggs per species per year per area are collected. After completion of laying, one egg per clutch is taken. Sample sites were chosen in such a way that the influence of the input of the three rivers, Elbe, Weser and Ems could be established (Fig. 1). Chlororganic residues, PCBs including single congeners, and mercury are analysed (methods:Becker et al., 1985a, b; Heidmann, 1986; Heidmann \& Büthe, 1986). As usual, the residue levels are given in $\mathrm{mg} / \mathrm{kg}$ fresh egg mass $(=\mathrm{ppm})$.

\section{RESULTS}

\section{Geographic variation}

The intersite variability of some contaminants studied in oystercatcher-eggs from 1987 is shown in Figure 2. Eggs from the sample areas in the western (area 1-6) and northern part of the German Wadden Sea (areas 14-15) were contaminated less than those from the estuaries of the Elbe (area 11) and the Weser (area 6,7) and those from the inner German Bight (areas 9, 12-13). Differences in geographic distribution between the various contaminants, however, were obvious: whereas eggs from the Elbe estuary and the inner German Bight were contaminated mostly with $\mathrm{HCB}$ and mercury, eggs collected at the Weser estuary were found to be contaminated mainly by PCBs and lindane. PCBs also predominated at Scharhörn (area 9). Greater amounts of HCB were found in the Dollart area (area 1) than in the other East Frisian areas. The eggs from all sites near the estuaries of the Elbe and the Weser were polluted mostly with $\Sigma$ DDT.

Corresponding geographic variations in 1987-residue levels were found in common tern eggs: In the Elbe estuary and the inner German Bight, the concentrations of the contaminants were higher than at other coastal sites (Becker, 1989).

This pronounced spatial variability was constant from year to year: the correspondent figures for the years 1981 and 1986 showed the same microgeographic pattern of contamination, also in other species (Becker et al., 1985a, b, 1988).

\section{Temporal trends 1981-1987}

The residue levels varied enormously between the years (Fig. 3). With regard to the majority of contaminants, the highest levels were found in 1987 and the lowest values in 1986. The predominant pollutants were the industrial chemicals PCBs, and mercury (common tern eggs from the Elbe estuary in 1987: PCBs $22.3 \pm 10.8 \mathrm{mg} / \mathrm{kg}$; mercury $7.4 \pm 2.9 \mathrm{mg} / \mathrm{kg}$ ).

\section{Interspecific differences}

Common tern eggs were more heavily contaminated than eggs of the oystercatcher (Fig. 3). Among seven species of birds breeding on the German Wadden Sea coast, eggs of the fish-consuming species common and sandwich tern Sterna sandvicensis were 

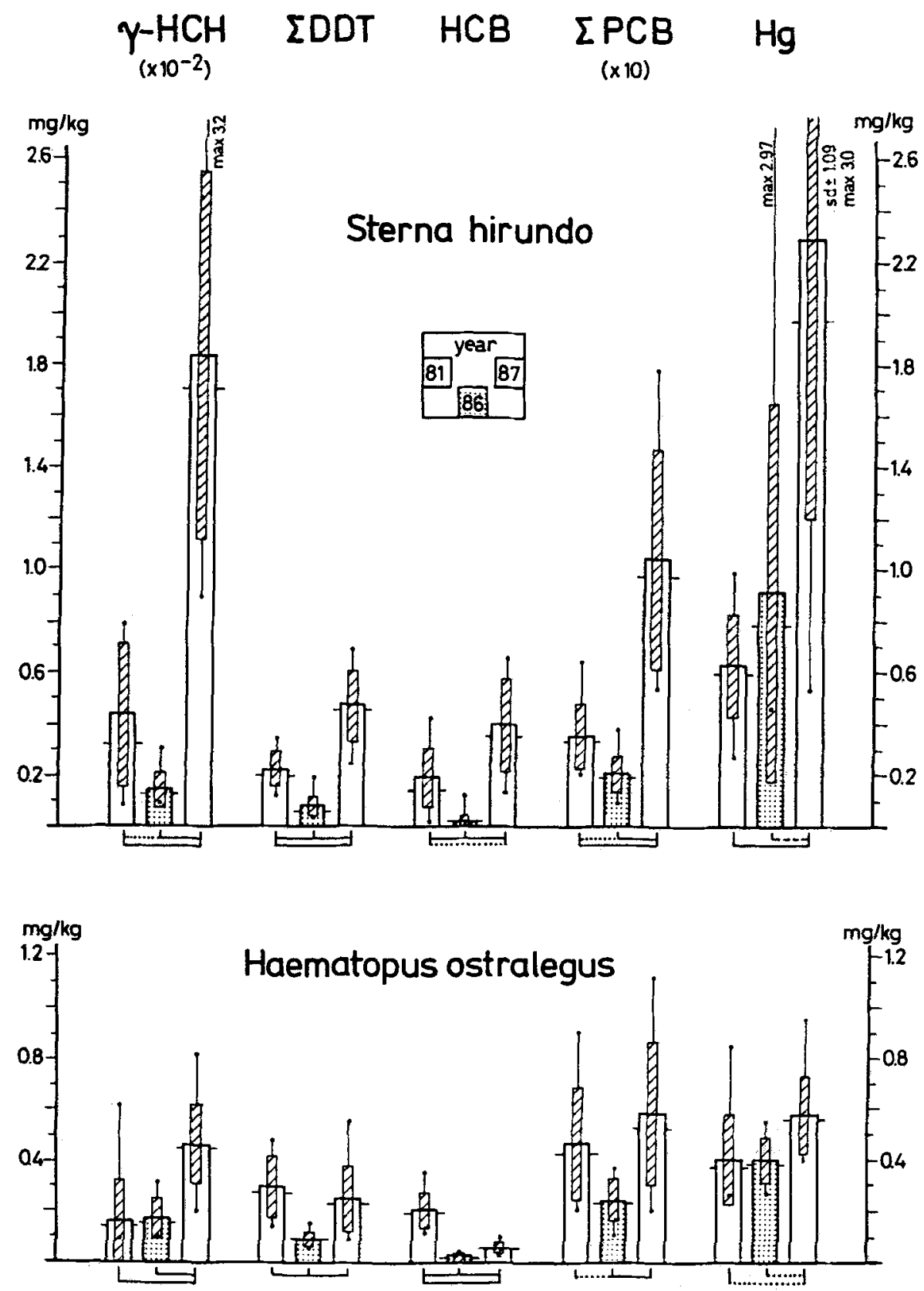

Fig. 3. Yearly differences $(1981,1986,1987)$ in concentrations of organochlorines and mercury in eggs of common terns and oystercatchers from the inner German Bight (area 12 in Fig. 1.). The levels are given in $\mathrm{mg} / \mathrm{kg}$ wet weight as in Fig. 2. Note the different factors in levels of $\gamma$-HCH and PCBs. 10 eggs per year per species were examined. Significant differences between years (Scheffé-test with $\log 10$ of residue levels) are marked thus: ....p $<0.05 ; \cdots \mathrm{p}<0.01 ; \ldots 0.001$ 
contaminated most; however, lindane was found in highest concentrations in shelduck Tadorna tadorna and ringed-plover Charadrius hiaticula (Becker et al., 1985a, b).

\section{DISCUSSION}

Birds as top predators have several advantages to offer in monitoring studies. They contain higher concentrations of residues than other animals, thus simplifying the chemical analysis; the within-sample variation in the concentrations of pollutants is lower in birds (eggs) than in other species of marine top predators (Gilbertson et al., 1987); and the residue levels can be related to population parameters, which are relatively well documented in birds. Owing to their high body loads of toxic chemicals, birds are particularly threatened, so that monitoring their contamination is required in any case for reasons of species protection.

The bird egg as sample unit has the following methodological advantages (see also NERC, 1983; Mineau et al., 1984; Ohlendorf et al., 1978; Gilbertson et al., 1987): eggs originate from a defined area and year; they reflect the contamination of breeding females (e.g. Vermeer \& Reynolds, 1970; Becker et al., 1989), which represent a healthy and reproductive part of the population; eggs being limited to the breeding season, the seasonal variability in birds contamination (e.g. Anderson \& Hickey, 1976) is reduced; it is not necessary to kill any adult bird; sampling one egg per clutch, the breeding success is only marginally reduced (intraclutch versus interclutch variation is low: Potts, 1968; Vermeer \& Reynolds, 1970; Mineau, 1982; Nisbet, 1982; Custer et al., 1983; Becker et al. 1989); sampling eggs takes little time; the samples are easy to handle; compared with tissues, eggs have a highly consistent composition and a high lipid content; it is precisely during the egg and early chick stage that birds react sensitively to toxic chemicals (Ohlendorf et al., 1978; Gilman et al., 1977; Mineau et al,, 1984); relationships between contamination, eggshell quality and hatching success can be studied, both in the field and through controlled experiments in the laboratory. On the other hand, eggs as samples do have some drawbacks: they are representative of only a part of the population, of only a part of the year and do not adequately indicate some of the heavy metals such as cadmium and lead (NERC, 1983; Becker et al., 1985b, 1989).

The spatial trends along the Wadden Sea coast show clearly the serious contamination of the birds breeding in the estuaries and in the inner German Bight. It can be concluded that with regard to the contaminants studied, the rivers Elbe and Weser are the major sources of pollution of the German North Sea, a fact which is corroborated by studies of invertebrates and fish (Rat von Sachverständigen, 1980; Anonymous, 1986; Umweltbundesamt, 1989). With increasing distance from the estuaries and with corresponding dilution of the pollutants, the concentrations of most chemicals investigated in North Frisia (Schleswig-Holstein) reached a range similar to those of East Frisia (Fig. 2). Comparing the concentrations between the Elbe and Weser sample sites, it can be concluded that the Weser has also contributed further to the pollution of the inner German Bight with lindane, DDT and metabolites and PCBs. Other studies, too, report that the contamination of sea- and shorebirds feeding inshore, such as oystercatchers and common terns, reflect the local pollution levels in the coastal marine environment (e.g. NERC, 1983; Custer et al., 1983; Nisbet \& Reynolds, 1984).

However, might not the contamination of the females just as well originate from the 
wintering areas and from the migration routes as from the breeding sites? The correspondence of the microgeographic pattern in the egg-residue levels among several years and species in the German Wadden Sea, irrespective of the species-specific feeding and migration habits of the birds, evidently shows, (a) that the egg contamination stems to a great extent from the feeding grounds near the breeding area where the pollutants are ingested during the pre-egg-laying period, and (b) that migrating species can also be valid indicators of the contamination levels at their breeding grounds. During the preegg-laying period, considerable quantities of food are required to produce eggs, especially in larids characterized by courtship feeding (e.g. common tern: Nisbet, 1977). As a result, the egg residues reflect the local contamination of the food web.

Postulated declines of some pollutants from 1981 to 1986 (Fig. 3; Becker et al., 1988) were not confirmed. We have as yet no explanation for the higher pollutant levels in 1987 , and are anxious for the results of the year 1988. Perhaps the high water-levels of the rivers in spring 1987 could have increased the rivers' pollutant loads (Flügge, 1988; Umweltbundesamt, 1989). Such year-to-year fluctuations only serve to underline the necessity for long-term studies to verify trends in contamination. Thus, in tern eggs from the Wadden Sea area, dieldrin, endrin and DDE showed a decline between the 1960s and the 1980s (Becker, 1989). Several other examples of temporal trends of chemicals in seabirds have been compiled by Gilbertson et al. (1987).

In the Wadden Sea, at the present time, insecticides are of only minor significance for the birds. The greatest quantities of residues now found in the eggs are industrial chemicals such as PCBs and mercury. In some regions, especially in the Elbe estuary or the inner German Bight, and in the highly polluted common tern, the levels of industrial chemicals now have a range endangering breeding success (cf. literature in Ohlendorf et al., 1978; Becker et al., 1985a, b).

One problem in monitoring chemicals is that high costs preclude the regular analysis of more than a few selected compounds of known toxicological relevance. As a result, many dangerous pollutants, possibly accumulated in birds, risk remaining undetected. This problem could be overcome by the additional monitoring of the breeding success in selected species at the known pollution hot spots, e.g. the Elbe estuary. Birds react sensitively to some toxic residues in their reproduction (see above). At the first sign of its impairment, e.g. through reduced eggshell-quality or lowered hatching success, intensive research into the causes could be started. Such biological effect monitoring would also produce better data on the chemical levels critical for the birds' breeding success.

Our investigations in the Wadden Sea (Becker et al., 1985a, b, 1988, this paper) and many other studies besides (summarized in Gilbertson et al., 1987) show that seabird eggs qualify as monitors of the contamination of the marine environment with toxic chemicals on a geographic and annual level. Thus, seabirds can function as an early warning system for the condition of the marine environment (Furness, 1987), a safeguard urgently required in the case of the North Sea. Until now, however, no top predator has been included in the European projects monitoring the sea, e.g. the "Joint Monitoring Programme" of the Commissions of Oslo and Paris. Our current studies are intended to contribute more basic information to justify the inclusion of a seabird species in an international program monitoring the contamination of the North Sea. 
Acknowledgements. This paper was supported by the Umweltbundesamt, Berlin. For the chemical analyses and constant cooperation I would like to thank A. Büthe, W. Heidmann and H. A. Rüssel from the Chemical Institute of the Tierärztliche Hochschule Hannover. A. Streich and C. Koepff kindly helped with the figures, statistics and text. Two anonymous referees submitted valuable suggestions for the improvement of the manuscript, and K. Wilson checked the English.

\section{LITERATURE CITED}

Anderson, D. W. \& Hickey, J., 1976. Dynamics of storage of organochlorine pollutants in herring gulls. - Envir. Pollut. 10, 183-200.

Anonymous, 1986. Gemeinsames Bund/Länder-Meßprogramm für die Nordsee - Gewässergütemessungen im Küstenbereich der Bundesrepublik Deutschland 1984/1985. Hannover.

Becker, P. H., 1989. Population and contamination studies in coastal birds with special reference to the common tern (Sterna hirundo). In: Bird population studies: their relevance to conservation and management. Ed, by C. M. Perrins, J. D. Lebreton \& G. J. M. Hirons. Oxford University Press, Oxford (in press).

Becker, P. H. \& Erdelen, M., 1987. Die Bestandsentwicklung von Brutvögeln der deutschen Nordseeküste 1950-1979. - J. Orn. 128, 1-32.

Becker, P. H., Büthe, A. \& Heidmann, W., 1985a. Schadstoffe in Gelegen von Brutvögeln der deutschen Nordseeküste. I. Chlororganische Verbindungen. - J. Orn. 126, 29-51.

Becker, P. H., Ternes, W. \& Rüssel, H. A., 1985b. Schadstoffe in Gelegen von Brutvögeln der deutschen Nordseeküste. II. Quecksilber. - J. Orn. 126, 253-262.

Becker, P. H., Büthe, A. \& Heidmann, W., 1988. Rückgänge von Schadstoffgehalten in Küstenvögeln? - J. Orn. 129, 104-106.

Becker, P. H., Conrad, B. \& Sperveslage, H., 1989. Chlororganische Verbindungen und Schwermetalle in weiblichen Silbermöwen (Larus argentatus) und ihren Eiern mit bekannter Legefolge. - Vogelwarte 35, 1-10.

Blus, D. J., Neely, B. S., Lamont, T. G. \& Mulheim, B., 1977. Residues of organochlorines and heavy metals in tissues and eggs of brown pelicans, 1969-73. - Pestic. Monitor. J. 11, 40-53.

Buchwald, K., 1985. Ist die Umweltbelastung von Deutscher Bucht, Inseln und Wattenmeer seit dem Nordseegutachten gewachsen? - Seevögel 6, 54-58.

Coulson, J. C., Deans, T. R. \& Potts, G. R., Robinson, J. \& Crabtree, A. N., 1972. Changes in organochlorine contamination of the marine environment of eastern Britain monitored by shag eggs. - Nature, Lond. 236, 454-456.

Custer, T. W., Erwin, R. M. \& Stafford, C., 1983. Organochlorine residues in common tern eggs from nine Atlantic coast colonies, 1980. - Colonial Waterbirds 6, 197-204.

Duinker, J. C. \& Koeman, J. H., 1978. Summary report on the distribution and effects of toxic pollutants (metals and chlorinated hydrocarbons) in the Wadden Sea. - Rep. Wadden Sea Working Group. 8, 45-54.

Flügge, G., 1989. Überwachung von Schadstoffen im Elbeästuar, - Forsch. Ber. Umweltbundesamt $87-064,1-46$.

Furness, R. W., 1987. Seabirds as monitors of the marine environment. - ICBP tech. Publ. 6, 217-230.

Gilbertson, M., Elliott, J. E. \& Peakall, D. B., 1987. Seabirds as indicators of marine pollution. - ICBP tech. Publ. 6, 231-248.

Gilman, A. P., Fox, G. A., Peakall, D. B., Temple, S., Carroll, T. R. \& Haymes, G. T., 1977. Reproductive parameters and egg contaminant levels of Great Lakes herring gulls. - J. Wildl. Mgmt 41, 458-468.

Glutz von Blotzheim, U. N., Bauer, K. M. \& Bezzel, E., 1975. Handbuch der Vögel Mitteleuropas. Akad. Verl.Ges. Wiesbaden 6, 1-840.

Glutz von Blotzheim, U. N. \& Bauer, K. M., 1982. Handbuch der Vögel Mitteleuropas. Akad. Verl.Ges. Wiesbaden, $8,1-1270$.

Goede, A. A., 1985. Mercury, selenium, arsenic and zinc in waders from the Dutch Wadden Sea. Envir. Pollut. 37, 287-309.

Heidmann, W. A., 1986. Isomer specific determination of polychlorinated biphenyls in animal tissues by gas chromatography mass spectrometry. - Chromatographia 22, 363-369. 
Heidmann, W. A. \& Büthe, A., 1986. Chlorpestizide und chlorhaltige Industriechemikalien. In: Rückstandsanalytik von Wirkstoffen in tierischen Produkten. Hrsg. von H. A. Rüssel. Thieme, Stuttgart, 166-177.

Koeman, J. H., 1971. Het voorkomen en de toxicologische betekenis van enkele chloorkoolwaterstoffen aan de Nederlandse kust in de periode 1965 tot 1970. Thesis, Univ. Utrecht, 139pp.

Mineau, P., 1982. Levels of major organochlorine contaminants in sequentially laid herring gull eggs. - Chemosphere 11,679-685.

Mineau, P., Fox, G. A., Norstrom, R. J., Weseloh, D. V., Hallen, D. J. \& Ellenton, J. A., 1984. Using the herring gull to monitor levels and effects of organochlorine contamination in the Canadian Great Lakes. In: Toxic contaminants in the Great Lakes. Ed. by J. O. Nriagu \& M. S. Simmons. Wiley, Chichester, 426-452.

Moksnes, M. T. \& Norheim G., 1986. Levels of chlorinated hydrocarbons and composition of PCB in herring gulls Larus argentatus eggs collected in Norway in 1969 compared to 1979-81. - Envir. Pollut. (Ser. B) 11, 109-116.

NERC, 1983. Contaminants in marine top predators. - NERC, Rep. Ser. (C) 23, 1-31.

Nisbet, I. C. T., 1977. Courtship-feeding and clutch size in common terns. In: Evolutionary ecology, Ed. by B. Stonehouse. Macmillan, London, 101-109.

Nisbet, I. C. T., 1982. Eggshell characteristics and organochlorine residues in common terns: Variation with egg sequence. - Colonial Waterbirds 5, 139-143.

Nisbet, I. C. T. \& Reynolds, L. M., 1984. Organochlorine residues in common terns and associated organisms, Massachusetts, USA, 1971-81. - Mar. Environ. Res. 11, 33-66.

Ohlendorf, H. M., Risebrough, R. W. \& Vermeer, K., 1978. Exposure of marine birds to environmental pollutants. - Wildl. Res. Rep. 9, 1-40.

Olsson, M. \& Reutergårdh, L., 1986. DDT and PCB pollution trends in the Swedish aquatic environment. - Ambio 15, 103-109.

Potts, G. R., 1968. Success of eggs of the shag on the Farne Islands, Northumberland, in relation to their content of dieldrin and pp' DDE. - Nature, Lond. 17, 1282-1284.

Rat von Sachverständigen für Umweltfragen, 1980. Umweltprobleme der Nordsee. Sondergutachten 1980. Kohlhammer, Stuttgart, 503 pp.

Robinson, J., Richardson, A., Crabtree, A. N., Coulson, J. C. \& Potts, F. R., 1967. Organochlorine residue in marine organisms. - Nature, Lond. 214, 1307-1311.

Swennen, C., 1972. Chlorinated hydrocarbons attacked the eider population in the Netherlands, TNO-nieuws $27,556-560$.

Tasker, M. L. \& Pienkowski, M. W., 1987. Vulnerable concentrations of birds in the North Sea. Nature Conservancy Council, Aberdeen, 38 pp.

Umweltbundesamt, 1989. Daten zur Umwelt 1988/89. Schmidt, Berlin, 612 pp.

Vermeer, K. \& Reynolds, L. M., 1970. Organochlorine residues in aquatic birds in the Canadian prairie provinces. - Can. Fld Nat. 84, 117-130. 